\title{
KEPRIBADIAN EKSTRAVERSI DAN KESEPIAN PADA REMAJA PANTI ASUHAN
}

\author{
Erwin Hogi ${ }^{1}$, Achmad Irvan Dwi Putra ${ }^{2}$ \\ ${ }^{1,2}$ Fakultas Psikologi Universitas Prima Indonesia \\ e-mail: ${ }^{1}$ hogi_erwin@yahoo.com
}

\begin{abstract}
Abstrak. Penelitian ini bertujuan untuk mengetahui hubungan kepribadian ekstraversi dengan kesepian. Hipotesis yang diajukan adalah terdapat hubungan negatif antara kepribadian ekstraversi dengan kesepian, dengan asumsi semakin tinggi kepribadian ekstraversi, maka semakin rendah kesepian begitu pula sebaliknya. Subjek penelitian yang digunakan dalam penelitian ini adalah remaja yang tinggal di Panti Asuhan Al Jam'iyatul Washliyah Pulo Brayan Medan sebanyak 123 orang yang dipilih dengan metode purposive sampling. Data diperoleh dari skala untuk mengukur kepribadian ekstraversi dan kesepian. Analisis data yang digunakan adalah menggunakan Pearson Product Moment Correlation melalui bantuan program SPSS 19.00 for Windows. Hasil analisis data menunjukkan koefisien korelasi sebesar $-0.731(\mathrm{p}<0.05)$ dan menunjukkan terdapat hubungan negatif antara kepribadian ekstraversi dengan kesepian. Hasil penelitian ini menunjukkan bahwa sumbangan yang diberikan kepribadian ekstraversi terhadap kesepian adalah sebesar 53.4 persen, selebihnya 46.6 persen dipengaruhi oleh faktor lain yang tidak diteliti. Dari hasil penelitian ini dapat ditarik kesimpulan bahwa hipotesis penelitian dapat diterima.
\end{abstract}

Kata kunci: kepribadian ekstraversi, kesepian

\begin{abstract}
This study aims to find relationship between extraversion personality and loneliness. The hypothesis of this study states that there is a negative relationship between extraversion personality and loneliness, assuming that the higher the extraversion personality is, the lower the loneliness will be and conversely. The subjects of this study were adolescents orphanage in Al Jam'iyatul Washliyah Medan consisting of 123 subjects selected by using purposive sampling method. Data were obtained from a scale to measure extraversion personality and loneliness. Analysis of the data used is Pearson Product Moment Correlation with SPSS 19.00 for Windows program. The results of data analysis showed a correlation coefficient of $-0.731(p<0.05)$ and showed that there is a negative relationship between extraversion personality and loneliness. The results of this study indicate that the contributions made by extraversion personality to the loneliness was 53.4 percent and the remaining 46.6 percent is influenced by other factors that are not examined. From these results it is concluded that the hypothesis is acceptable.
\end{abstract}

Keywords: extraversion personality, loneliness 
Masa remaja merupakan masa transisi antara masa anak-anak menuju masa dewasa. Masa di mana individu meninggalkan masa anak-anaknya memasuki masa dewasa (Batubara, dalam Utami, Ahmad, \& Ifdil, 2017). Remaja dituntut untuk menguasai tugas perkembangannya, salah satunya perkembangan sosial. Pada periode ini, individu tidak hanya dituntut untuk bersosialisasi dengan keluarga, namun juga dengan masyarakat sehingga individu dapat berbaur dan menyesuaikan diri dengan norma yang berlaku di masyarakat (Prayitno, dalam Utami, dkk., 2017). Pada masa transisi inilah, emosi remaja terkadang menjadi kurang stabil, sehingga tidak jarang ditemui remaja yang melakukan perilaku menyimpang dan negatif jika terjebak dalam lingkungan pergaulan yang salah. Remaja yang mampu beradaptasi tentu akan memiliki banyak relasi dengan teman sebayanya sedangkan untuk remaja yang tidak mampu menyesuaikan diri akan merasa terpisah dengan lingkungannya, merasa hampa, dan juga merasa kosong. Ketidakmampuan dalam memenuhi tugas perkembangan ini menyebabkan remaja akan merasa dikucilkan, terasing, bahkan merasa kesepian.

Perasaan hampa dan kosong dapat mengarah pada perasaan kesepian (Johnson, 2014). Kesepian merupakan fenomena umum yang sering terjadi dalam kehidupan manusia. Kesepian dapat berasal dari berbagai faktor di antaranya genetik, kurangnya pengalaman sosial, dan gaya pendekatan dengan teman sebaya yang salah (Baron \& Branscombe, 2012).

Perasaan kesepian dalam jangka waktu lama mengakibatkan seseorang melakukan perilaku-perilaku yang menyimpang seperti konsumsi alkohol dan obat-obatan terlarang. Kesepian juga menjadi salah satu faktor seseorang melakukan bunuh diri (Azizog־lu; DiTommaso; McWhirter, dalam Cecen, 2007). Berdasarkan studi yang pernah dilakukan, kesepian lebih banyak dialami oleh remaja dibandingkan orang dewasa (Heinrich \& Gullone, dalam Myers, 2012).

Fenomena kesepian telah banyak diteliti pada berbagai macam subjek, baik itu pada anak-anak, remaja, orang dewasa, mahasiswa, orang dengan lanjut usia, orang tua tunggal, perantau, maupun anak penghuni panti asuhan. Secara khusus, pada anak yang tinggal di panti asuhan memiliki peluang lebih besar untuk mengalami perasaan kesepian. Pada umumnya, anak-anak yang tinggal di panti asuhan adalah anak-anak yang memiliki keterbatasan ekonomi, telah kehilangan salah satu ataupun kedua orang tuanya, ataupun lainnya.

Hal tersebut sesuai dengan hasil survei awal yang peneliti lakukan di Panti Asuhan Al Jam'iyatul Washliyah Pulo Brayan Medan. Setelah dilakukan observasi dan wawancara pada para anak yang tinggal di panti asuhan tersebut, khususnya para remaja, mereka mengaku sering kali merasa asing dengan panti asuhan. Beberapa dari mereka yang telah tinggal di panti mengaku sering merasa tidak diterima dengan ramah oleh anak lainnya sehingga membuat mereka teringat kembali dengan keadaan rumah dan orang tuanya dulu. Mereka mengatakan setiap anak meskipun telah dewasa, pasti tidak ingin tinggal terpisah dari orang tuanya. Namun karena alasan keterbatasan kemampuan ekonomi orang tuanya, mereka pun terpaksa hidup terpisah dan tinggal di panti asuhan. Hal ini sering kali menyebabkan mereka merasa kesepian meskipun hidup bersama dengan 
banyak anak asuh. Hasil wawancara peneliti diperkuat dengan observasi yang didapatkan di lapangan ketika peneliti datang. Beberapa remaja terlihat lebih memilih menyendiri dibanding berbaur dengan anak-anak lainnya. Setelah peneliti wawancarai, subjek mengaku sedang ingin menyendiri dan tidak ada teman yang memiliki niat untuk menjalin komunikasi dengannya karena ia baru tinggal selama beberapa bulan di panti asuhan tersebut.

Kesepian merupakan pengalaman yang tidak menyenangkan saat individu merasakan perbedaan antara pola jaringan sosial mereka yang diinginkan dan terpenuhi. Definisi ini menganggap kesepian sebagai pengalaman negatif subjektif dan pengalaman yang menyebabkan frustrasi yang terkait dengan persepsi ketidakcocokan mengenai domain hubungan sosial (Peplau \& Perlman, dalam Vanhalst, Goosens, Luyckx, Scholte, \& Engels, 2013). Kesepian dapat menyebabkan seseorang tidak mau membentuk hubungan interpersonal dan kesulitan dalam membangun hubungan sosial dengan orang lain (Arnett, dalam Nayyar \& Singh, 2011). Kesepian juga dapat didefinisikan sebagai keadaan dimana terdapat kekurangan antara tingkat keterlibatan sosial, keinginan untuk menghabiskan waktu sendirian, dan isolasi sosial yang mengacu pada tingkat integrasi individu dan kelompok ke dalam lingkungan sosial yang lebih luas (Victor, Sasha, \& John, 2009).

Kesepian dapat dihubungkan dengan dan juga berpotensi dipengaruhi oleh trait kepribadian, shyness, dan kepribadian ekstraversi (Uruk \& Demir, dalam Bevinn, 2011). Pendapat tersebut juga didukung oleh Hawkley (dalam Riva \& Eck, 2016) yang menyatakan bahwa kepribadian ekstraversi dapat memengaruhi tingkat kesepian seseorang. Semakin tinggi kepribadian ekstraversi yang dimiliki seseorang, maka tingkat kesepian akan semakin rendah. Sehingga, kepribadian ekstraversi berkorelasi negatif dengan kesepian, yang berarti rendahnya kepribadian ekstraversi juga dapat berdampak pada tingginya perasaan kesepian.

Kepribadian ekstraversi adalah himpunan bagian dari sifat dengan model yang berbeda, yang di dalamnya mencakup sifat-sifat suka bersosialisasi, suka mencari sensasi, emosi positif, dan optimisme. Ekstraversi dapat didefinisikan dalam pengertian sempit dan pengertian yang luas. Dalam pengertian sempit, ekstraversi adalah individu yang senang membangun hubungan sosial dengan orang lain. Dalam definisi yang luas, ekstraversi dapat mencakup banyak komponen perilaku yang berbeda-beda seperti ketegasan, kehangatan, emosi positif, serta senang melakukan aktivitas (Depue \& Collins, dalam Weiner, 2003). Kepribadian ekstraversi merupakan sikap yang menjelaskan aliran psikis ke arah luar sehingga orang yang bersangkutan akan memiliki orientasi objektif dan menjauh dari subjektif (Jung, dalam Sarinah, 2017).

Kesepian dapat dirasakan setiap manusia pada berbagai usia tahap perkembangan. Pada salah satu penelitian terdahulu yang dilakukan terhadap 100 mahasiswa-mahasiswi Universitas Panjab, Chandigarh ditemukan hasil bahwa kepribadian ekstraversi berkorelasi negatif dengan kesepian. Dimana semakin tinggi kepribadian ekstraversi maka semakin rendah kesepian yang dirasakan mahasiswa-mahasiswi, dan sebaliknya 
semakin rendah kepribadian ekstraversi, maka semakin tinggi kesepian yang dirasakan oleh mahasiswa-mahasiswi tersebut (Nayyar \& Singh, 2011).

Peneliti tertarik untuk mengaitkan kepribadian ekstraversi dengan kesepian pada remaja yang tinggal menetap di panti asuhan. Kesepian sering kali dirasakan oleh remaja yang tinggal di panti asuhan karena mereka telah tinggal terpisah dari orang tuanya ataupun karena telah kehilangan orang tuanya. Lingkungan panti asuhan yang memiliki peraturan-peraturan yang harus ditaati menyebabkan lingkungan sosial remaja panti pun lebih terbatas. Sehingga, perasaan kesepian ini sangat minim untuk diminimalisir dengan cara menjalin hubungan pertemanan dengan orang-orang baru yang berada di luar panti.

Penelitian terdahulu oleh Saklofske, dkk., (1986) dalam penelitian yang melibatkan 101 mahasiswa-mahasiswi Universitas Canadian telah menemukan bahwa kesepian berkorelasi negatif dengan kepribadian ekstraversi. Orang-orang yang merasakan kesepian memiliki kontak interpersonal dan interaksi dengan orang lain yang lebih sedikit, juga akibat dari dukungan jaringan sosial yang kurang luas. Berbagai studi yang telah dilakukan menunjukkan orang yang kesepian memiliki kepribadian ekstraversi yang rendah.

Berdasarkan uraian-uraian sebelumnya, maka peneliti tertarik untuk meneliti hubungan antara kepribadian ekstraversi dengan kesepian pada remaja yang tinggal di Panti Asuhan Al Jam'iyatul Washliyah Pulo Brayan di Kota Medan. Adapun yang membedakan penelitian ini dengan penelitian terdahulu adalah karakteristik subjek dalam penelitian yang meliputi remaja yang tinggal menetap di panti asuhan, berusia 13-16 tahun, dan telah kehilangan salah satu ataupun kedua orang tuanya (yatim/piatu/yatim-piatu) guna mendapatkan gambaran kesepian yang lebih utuh pada remaja yang telah kehilangan orang tuanya. Tujuan dari penelitian ini untuk mengetahui hubungan antara kepribadian ekstraversi dengan kesepian. Manfaat praktis yang diharapkan dari penelitian ini jika hipotesis diterima adalah pihak pengurus, pengawas, dan pimpinan panti asuhan agar dapat mengadakan sharing group dengan semua anak asuh agar mengantisipasi munculnya perasaan kesepian pada anak asuh. Hipotesis yang diajukan dalam penelitian ini adalah terdapat hubungan negatif dan signifikan antara kepribadian ekstraversi dengan kesepian. Dengan asumsi semakin tinggi kepribadian ekstraversi maka semakin rendah kesepian subjek penelitian demikian pula sebaliknya, semakin rendah kepribadian ekstraversi pada subjek maka semakin tinggi kesepian yang dirasakannya.

\section{METODE}

Penelitian ini menggunakan desain penelitian kuantitatif dengan teknik analisis data korelasional. Penelitian korelasional sebagai teknik pengelolaan data dengan cara mengorelasikan atau menghubungkan dua data variabel atau lebih untuk mengetahui tingkat keeratan hubungan (Siswanto, Susila, \& Suyanto, 2017). Dalam penelitian ini menggunakan teknik pengujian korelasi Pearson Product Moment untuk melihat hubungan variabel bebas dengan variabel terikat. 
Populasi dalam penelitian ini sebanyak 315 anak yang tinggal di Panti Asuhan Al Jam'iyatul Washliyah Pulo Brayan Medan. Adapun alasan dipilihnya remaja yang tinggal di panti asuhan guna mengontrol variabel kesepian pada remaja yang telah kehilangan salah satu ataupun kedua orang tuanya dan tinggal menetap di panti asuhan. Penelitian ini melibatkan 123 remaja Panti Asuhan Al Jam'iyatul Washliyah Pulo Brayan yang dipilih dengan teknik purposive sampling dengan kriteria subjek berusia 13-16 tahun, anak yatim/piatu/yatim-piatu, dan remaja yang tinggal menetap di panti asuhan.

Alat pengumpul data dalam penelitian ini menggunakan skala pengukuran untuk mengukur kepribadian ekstraversi dan kesepian. Skala Kepribadian Ekstraversi peneliti kembangkan berdasarkan aspek-aspek ekstraversi yang dikemukakan oleh Depue dan Collins (dalam Weiner, 2003) yang meliputi aspek sociability, aspek agency, aspek activation, aspek impulsive-sensation seeking, dan aspek positive emotions. Total aitem untuk skala kepribadian ekstraversi sebanyak 40 aitem yang terdiri dari 8 aitem untuk aspek sociability yang terbagi menjadi 5 aitem favourable dan 3 aitem unfavourable, aspek agency terdiri dari 9 aitem yang terbagi menjadi 5 aitem favourable dan 4 aitem unfavourable, aspek activation terdiri dari 7 aitem yang terbagi menjadi 4 aitem favourable dan 3 aitem unfavourable, aspek impulsive-sensation seeking terdiri dari 7 aitem yang terbagi menjadi 4 aitem favourable dan 3 aitem unfavourable dan aspek positive emotions yang terdiri dari 9 aitem yang terbagi menjadi 4 aitem favourable dan 5 aitem unfavourable. Skala Kesepian peneliti kembangkan berdasarkan aspek-aspek kesepian yang dipaparkan oleh Weiss (dalam Margalit, 2010) yang meliputi aspek kesepian emosional dan aspek kesepian sosial. Total aitem untuk skala kesepian sebanyak 40 aitem yang terdiri dari 20 aitem untuk aspek kesepian emosional yang terbagi menjadi 10 aitem favourable dan 10 aitem unfavourable. Sedangkan, untuk aspek kesepian sosial terdiri dari 20 aitem yang terbagi menjadi 10 aitem favourable dan 10 aitem unfavourable.

Sebelum pengambilan data penelitian, peneliti melaksanakan try out terlebih dahulu terhadap 72 subjek remaja yang sesuai dengan karakteristik yang ditetapkan pada subjek penelitian di Panti Asuhan Al Jam'iyatul Washliyah Jalan Ismailiyah No. 82 di Kota Medan. Setelah dilakukan try out, hasil uji coba skala dijelaskan di bawah ini.

Hasil uji validitas terhadap Skala Kepribadian Ekstraversi ini menunjukkan nilai $\mathrm{r}_{i x}$ bergerak dari 0.299 hingga 0.594 sehingga sebanyak 7 aitem dinyatakan gugur. Total aitem yang digunakan dalam penelitian ini sebanyak 33 aitem untuk mengukur kepribadian ekstraversi subjek penelitian. Reliabilitas Skala Kepribadian Ekstraversi ini diuji dengan teknik Alpha Cronbach yang menunjukkan hasil $\alpha=0.886$. Sehingga, dapat disimpulkan Skala Kepribadian Ekstraversi ini sudah reliabel karena sudah memenuhi koefisien reliabilitas yang baik, yaitu di atas 0.6 (Sugiyono, dalam Siswanto, dkk., 2017).

Hasil uji validitas terhadap Skala Kesepian ini menunjukkan nilai $\mathrm{r}_{i x}$ bergerak dari 0.268 hingga 0.674 sehingga sebanyak 3 aitem dinyatakan gugur. Total aitem yang digunakan dalam penelitian ini sebanyak 37 aitem untuk mengukur kesepian pada subjek penelitian. Reliabilitas Skala Kesepian ini diuji dengan teknik Alpha Cronbach yang menunjukkan hasil $\alpha=0.920$. Sehingga, dapat disimpulkan Skala Kesepian ini sudah reliabel karena 
sudah memenuhi koefisien reliabilitas yang baik, yaitu di atas 0.6 (Sugiyono, dalam Siswanto, dkk., 2017).

Setelah mendapatkan hasil uji validitas dan reliabilitas yang baik, peneliti kemudian menyebarkan angket kepada 123 remaja yang menjadi subjek dalam penelitian ini. Setelah data terkumpul, selanjutnya peneliti melakukan pengolahan data dan uji hipotesis dengan Pearson Product Moment Correlation.

Hasil Pearson Product Moment Correlation dapat dikatakan tidak menyimpang apabila memenuhi syarat uji asumsi klasik data yang mana mensyaratkkan data harus terdistribusi normal dan memiliki hubungan linear antar variabel yang diteliti (Hadi, dalam Siswanto, dkk., 2017). Berdasarkan hasil analisis, ditemukan bahwa semua syarat untuk menggunakan teknik Pearson Product Moment Correlation terpenuhi, yaitu data terdistribusi normal dan kedua variabel yang peneliti teliti yaitu kepribadian ekstraversi dan kesepian memiliki hubungan yang linear.

\section{H A S I L}

Tabel 1. Data Deskriptif Kepribadian Ekstraversi dan Kesepian

\begin{tabular}{lll}
\hline & $\begin{array}{l}\text { Kepribadian } \\
\text { Ekstraversi }\end{array}$ & Kesepian \\
\hline Skor Minimum & 37 & 76 \\
\hline Skor Maksimum & 132 & 147 \\
\hline Skor Rata-rata & 71.26 & 105.8 \\
\hline Standar Deviasi & 15.858 & 15.938 \\
\hline Kategori Rendah (Persentase) & $39(31.71 \%)$ & $0(0 \%)$ \\
\hline Kategori Sedang (Persentase) & $82(66.66 \%)$ & $76(61.79 \%)$ \\
\hline Kategori Tinggi (Persentase) & $2(1.63 \%)$ & $47(38.21 \%)$ \\
\hline
\end{tabular}

Berdasarkan data pada tabel 1, untuk variabel kepribadian ekstraversi, terdapat 39 subjek (31.71 persen) yang memiliki kepribadian ekstraversi rendah, terdapat 82 subjek (66.66 persen) yang memiliki kepribadian ekstraversi sedang, dan terdapat 2 subjek (1.63 persen) yang memiliki kepribadian ekstraversi tinggi. Berdasarkan penjelasan di atas maka dapat disimpulkan bahwa rata-rata subjek penelitian memiliki kepribadian ekstraversi sedang.

Dari skala kepribadian ekstraversi yang diisi subjek, maka diperoleh mean empirik sebesar 70.3 dengan standar deviasi 16.5. Apabila mean empirik > mean hipotetik maka hasil penelitian yang diperoleh akan dinyatakan tinggi dan sebaliknya jika mean empirik $<$ mean hipotetik maka hasil penelitian akan dinyatakan rendah. Hasil analisis untuk skala kepribadian ekstraversi diperoleh mean empirik < mean hipotetik yaitu $71.26<82.5$ maka dapat disimpulkan bahwa kepribadian ekstraversi pada subjek penelitian lebih rendah daripada populasi pada umumnya. 
Selanjutnya, untuk hasil kategorisasi variabel kesepian dari jumlah subjek 123 remaja menunjukkan bahwa tidak terdapat subjek (0 persen) yang memiliki kesepian rendah, terdapat 76 subjek (61.79 persen) yang memiliki kesepian sedang, dan terdapat 47 subjek (38.21 persen) yang memiliki kesepian tinggi. Berdasarkan penjelasan tersebut maka dapat disimpulkan bahwa rata-rata subjek penelitian memiliki kesepian sedang.

Dari skala kesepian yang diisi subjek, maka diperoleh mean empirik sebesar 105.8 dengan standar deviasi 15.938. Apabila mean empirik > mean hipotetik maka hasil penelitian yang diperoleh akan dinyatakan tinggi dan sebaliknya jika mean empirik < mean hipotetik maka hasil penelitian akan dinyatakan rendah. Hasil analisis untuk skala kesepian diperoleh mean empirik > mean hipotetik yaitu 105.8>92.5 maka dapat disimpulkan bahwa kesepian pada subjek penelitian lebih tinggi daripada populasi pada umumnya.

Hasil uji normalitas sebaran dilakukan agar dapat mengetahui apakah setiap variabel penelitian telah terdistribusi secara normal atau tidak. Uji normalitas sebaran dalam penelitian ini menggunakan uji Kolmogorov Smirnov Test. Data dikatakan terdistribusi normal jika p>0.05 (Priyatno, 2011). Berdasarkan hasil uji normalitas sebaran, dapat diketahui uji normalitas sebaran pada variabel kepribadian ekstraversi diperoleh koefisien sig 1 (satu) arah dari variabel kepribadian ekstraversi sebesar 0.203 ( $\mathrm{p}>0.05$ ), yang berarti bahwa data pada variabel kepribadian ekstraversi memiliki sebaran atau terdistribusi normal. Uji normalitas sebaran yang dilakukan terhadap variabel kesepian diperoleh koefisien sig uji 1 (satu) arah dari variabel kesepian sebesar 0.386 ( $p>0.05)$, yang berarti bahwa data pada variabel kesepian memiliki sebaran atau terdistribusi normal.

Uji linearitas hubungan dimaksudkan untuk mengetahui derajat hubungan antara variabel bebas dengan variabel terikat dalam penelitian ini, yaitu kepribadian ekstraversi dan kesepian, sebagai syarat dilakukannya pengujian analisis data korelasional Pearson Product Moment dengan tujuan untuk melihat apakah kedua variabel tersebut memiliki hubungan yang linear atau tidak. Sebagai kriterianya apabila nilai signifikansi $<0,05$ maka dinyatakan memiliki derajat hubungan yang linear. Berdasarkan hasil pada hasil pengujian linearitas, dapat dilihat nilai sig sebesar 0.000 yang mana $\mathrm{p}<0.05$, sehingga dapat disimpulkan bahwa kedua variabel memiliki hubungan linear dan telah memenuhi syarat untuk dilakukan analisis Pearson Product Moment Correlation.

Tabel 2. Hasil Uji Hipotesis

\begin{tabular}{llllll}
\hline Analisis & $\begin{array}{l}\text { Pearson Product } \\
\text { Moment }\end{array}$ & $\mathrm{R}$ & $\mathrm{R}$ Square & $\begin{array}{l}\text { Std. Error of the } \\
\text { Estimate }\end{array}$ & \\
\hline Koefisien & -0.731 & -0.731 & 0.534 & 10.921 & \\
\hline Sig. & 0.000 & & & & \\
\hline
\end{tabular}

Berdasarkan hasil uji hipotesis dengan teknik Pearson Product Moment Correlation pada tabel 2 ditemukan bahwa terdapat hubungan negatif yang kuat dan signifikan antara 
kepribadian ekstraversi dengan kesepian $(\mathrm{r}=-0.731, \mathrm{p}=0.000<0.05)$. Hal ini menunjukkan bahwa adanya korelasi negatif yang signifikan antara kepribadian ekstraversi dengan kesepian sehingga dikategorikan hubungan yang kuat (Priyatno, 2011). Dari hasil perhitungan tersebut, maka hipotesis yang diajukan dalam penelitian ini menunjukkan terdapat hubungan negatif antara kepribadian ekstraversi dengan kesepian pada remaja yang tinggal di Panti Asuhan Al Jam'iyatul Washliyah Pulo Brayan dapat diterima.

Dalam penelitian ini diperoleh koefisien determinasi $\left(\mathrm{R}^{2}\right)$ sebesar 0.534. Berdasarkan hasil tersebut, dapat disimpulkan bahwa sumbangan 53.4 persen kepribadian ekstraversi memengaruhi kesepian dan selebihnya sebesar 46.6 persen dipengaruhi oleh faktor-faktor lain yang tidak diteliti pada penelitian ini, seperti kecerdasan sosial, dukungan keluarga, kepribadian introversi, cybervictimization, penggunaan internet, kualitas komunikasi, kebutuhan afiliasi, presentasi diri, psychological well-being, dan self disclosure. Dengan demikian, dapat diambil kesimpulan bahwa semakin tinggi kepribadian ekstraversi yang dimiliki remaja yang tinggal di Panti Asuhan Al Jam'iyatul Washliyah Pulo Brayan maka semakin tinggi kesepian yang mereka rasakan. Sebaliknya, semakin rendah kepribadian ekstraversi yang dimiliki remaja yang tinggal di Panti Asuhan Al Jam'iyatul Washliyah Pulo Brayan maka semakin rendah kesepian.

\section{DISKUSI}

Hasil penelitian ini menunjukkan adanya hubungan negatif yang kuat dan signifikan antara kepribadian ekstraversi dengan kesepian pada remaja Panti Asuhan Al Jam'iyatul Washliyah Pulo Brayan Medan. Hubungan yang negatif ini menjelaskan semakin tinggi kepribadian ekstraversi pada remaja yang tinggal di Panti Asuhan Al Jam'iyatul Washliyah Pulo Brayan Medan, maka semakin rendah kesepian yang mereka rasakan. Sebaliknya, semakin rendah kepribadian ekstraversi pada remaja yang tinggal di Panti Asuhan Al Jam'iyatul Washliyah Pulo Brayan Medan, maka semakin tinggi kesepian yang mereka rasakan. Sehingga, hipotesis yang diajukan dalam penelitian ini diterima.

Temuan penelitian ini sesuai dengan pernyataan yang dipaparkan oleh Uruk dan Demir (dalam Bevinn, 2011) bahwa kesepian dapat dihubungkan dengan dan juga berpotensi dipengaruhi oleh trait kepribadian, shyness, dan kepribadian ekstraversi. Hawkley (dalam Riva \& Eck, 2016) juga menegaskan bahwa kepribadian ekstraversi dapat memengaruhi tingkat kesepian seseorang. Semakin tinggi kepribadian ekstraversi yang dimiliki seseorang, maka tingkat kesepian akan semakin rendah. Sehingga, kepribadian ekstraversi berkorelasi negatif dengan kesepian, yang berarti rendahnya kepribadian ekstraversi juga dapat berdampak pada tingginya perasaan kesepian.

Hasil yang senada juga didapatkan pada penelitian yang dilakukan oleh Saklofske dan Yackulic (1989) tentang "Personality Predictors of Loneliness" pada 258 mahasiswamahasiswi pada sebuah universitas menunjukkan adanya korelasi yang negatif antara kepribadian ekstraversi dengan kesepian pada mahasiswa laki-laki juga pada mahasiswi perempuan. Penelitian senada yang dilakukan oleh Nayyar dan Singh (2011) pada 100 mahasiswa-mahasiswi Universitas Panjab, Chandigarh menunjukkan bahwa terdapat hubungan negatif yang signifikan antara kepribadian ekstraversi dan kesepian. Hal ini 
menunjukkan semakin tinggi kepribadian ekstraversi pada mahasiswa-mahasiswi Universitas Panjab maka semakin rendah kesepian. Individu yang memiliki kepribadian ekstraversi yang tinggi lebih menyukai dilibatkan dalam suatu aktivitas sosial dan memiliki jaringan pertemanan mereka sendiri selain dari keluarga. Sehingga, individu dengan kepribadian ekstraversi yang tinggi merasa lebih puas dalam kualitas relasi sosialnya dan minim merasakan kesepian.

Hasil penelitian ini juga sejalan dengan beberapa penelitian yang telah dilakukan sebelumnya yaitu penelitian Vanhalst, dkk., (2013) terhadap 428 keluarga yang berpartisipasi dalam penelitian ini dan menunjukkan adanya korelasi negatif yang signifikan antara kepribadian ekstraversi dengan kesepian. Hasil penelitian ini berbunyi semakin tinggi kepribadian ekstraversi, maka semakin rendah kesepian dan sebaliknya, semakin rendah kepribadian ekstraversi, maka semakin tinggi kesepian. Orang-orang yang merasakan kesepian memiliki kontak interpersonal dan interaksi dengan orang lain yang lebih sedikit, juga akibat dari dukungan jaringan sosial yang kurang luas. Berbagai studi yang telah dilakukan menunjukkan orang yang kesepian memiliki kepribadian ekstraversi yang rendah. Hasil penelitian lain yang dilakukan oleh Nayyar dan Singh (2011) pada 100 mahasiswa-mahasiswi Universitas Panjab, Chandigarh juga menunjukkan bahwa terdapat hubungan negatif yang signifikan antara kepribadian ekstraversi dan kesepian. Hal ini menunjukkan semakin tinggi kepribadian ekstraversi pada mahasiswa-mahasiswi Universitas Panjab maka semakin rendah kesepian dan sebaliknya semakin rendah kepribadian ekstraversi yang dimiliki mahasiswa-mahasiswi Universitas Panjab maka semakin tinggi kesepian yang mereka rasakan.

Berdasarkan observasi dan wawancara lanjutan terhadap remaja yang tinggal di Panti Asuhan Al Jam'iyatul Washliyah Pulo Brayan sebanyak 82 subjek atau 66.66 persen menunjukkan tingkat kepribadian ekstraversi pada kategori sedang. Aspek sociability menonjol dalam menggambarkan kepribadian ekstraversi pada subjek dengan kategori sedang pada remaja yang tinggal di Panti Asuhan Al Jam'iyatul Washliyah Pulo Brayan. Para subjek menyatakan bahwa kemampuan mereka tidak pernah diakui oleh temantemannya. Berdasarkan informasi yang mereka berikan, sering kali teman-temannya menyepelekan apapun yang dapat mereka kerjakan dengan baik. Misalnya, salah seorang subjek mengaku bahwa pada Hari Minggu para anak panti melakukan kegiatan kebersihan. Pengurus panti sering meminta para anak panti lainnya untuk mencontoh si subjek tersebut karena kebersihannya. Namun, anak panti yang lain malah sering memandangnya sedang mencari perhatian dan hal yang ia kerjakan memanglah hal yang mudah. Aspek positive emotions juga dapat menggambarkan kepribadian ekstraversi yang berada di kategori sedang pada remaja yang tinggal di Panti Asuhan Al Jam'iyatul Washliyah Pulo Brayan. Sebagai seorang remaja, salah tugas perkembangannya adalah membangun relasi sosial dan membangun hubungan intim dengan lawan jenisnya. Namun, jika tugas perkembangan ini tidak terpenuhi, remaja dapat merasakan perasaan sedih dan kesepian. Hal ini sesuai dengan hasil wawancara yang telah dilakukan pada remaja panti, para subjek merasa sedih karena tidak memiliki banyak teman untuk diajak berbicara. 
Sebanyak 39 subjek atau 31.71 persen subjek menunjukkan tingkat kepribadian ekstraversi pada kategori rendah. Hasil wawancara pada para subjek menunjukkan bahwa para remaja panti asuhan juga sering merasa pesimis akan masa depan mereka. Hal ini membuat para remaja tidak tekun dalam belajar. Alasan lain yang mereka kemukakan adalah karena minimnya dukungan dari orang lain. Aspek activation juga menonjol dalam menggambarkan rendahnya kepribadian ekstraversi pada remaja yang tinggal di Panti Asuhan Al Jam'iyatul Washliyah Pulo Brayan. Para subjek menyatakan bahwa mereka menjadi enggan untuk berbicara dengan orang yang baru dikenal dan lebih pasif dalam hubungan sosial, baik itu pada anak panti asuhan yang baru masuk ataupun orang luar yang datang berkunjung.

Dari keseluruhan data yang telah diperoleh, hanya ditemukan 2 subjek atau 1.63 persen subjek yang memiliki kepribadian ekstraversi pada kategorisasi yang tinggi. Hasil wawancara menunjukkan para subjek cenderung senang untuk belajar segala sesuatu yang sebelumnya belum mereka pelajari, terutama menyangkut life skills. Beberapa kali di panti asuhan ini telah dilakukan penelitian dan beberapa di antaranya merupakan penelitian yang bersifat eksperimental yang diberikan kepada para subjek untuk mengatasi permasalahan-permasalahan yang dialami oleh para subjek. Para subjek mengaku tertarik untuk belajar hal-hal yang belum mereka ketahui tersebut. Hal tersebut menunjukkana aspek impulsive sensation-seeking ditemukan menonjol pada para subjek. Selain pada aspek impulsive sensation-seeking, aspek positive emotions juga dominan pada subjek dengan kepribadian ekstraversi yang tinggi. Berdasarkan wawancara yang telah dilakukan, para subjek mengaku senang jika ada anak-anak panti lain yang mencari mereka. Mereka merasa diinginkan dan diakui sebagai seorang teman. Sehingga, mereka merasa diterima dan tidak merasa diasingkan.

Selain kepribadian ekstraversi, penelitian ini juga meneliti kesepian remaja yang tinggal di Panti Asuhan Al Jam'iyatul Washliyah Pulo Brayan. Sebanyak subjek 123 remaja menunjukkan bahwa tidak terdapat subjek (0 persen) yang memiliki kesepian rendah, terdapat 76 subjek (61.79 persen) yang memiliki kesepian sedang, dan terdapat 47 subjek (38.21 persen) yang memiliki kesepian tinggi. Berdasarkan penjelasan tersebut, dapat dipahami remaja yang tinggal di Panti Asuhan Al Jam'iyatul Washliyah Pulo Brayan rata-rata memiliki kesepian yang berada pada kategori tinggi.

Berdasarkan observasi dan wawancara lanjutan terhadap remaja yang tinggal di Panti Asuhan Al Jam'iyatul Washliyah Pulo Brayan sebanyak 76 subjek atau 61.79 persen subjek menunjukkan tingkat kesepian yang sedang. Peneliti menemukan para subjek menyatakan bahwa teman-teman di sekeliling mereka tidak semuanya ingin berteman dengan mereka. Hal ini membuat para subjek merasa sedih karena tidak memiliki siapapun di samping mereka. Para subjek juga merasa menghadapi permasalahannya seorang diri. Selain aspek kesepian emosional, aspek kesepian sosial juga ditemukan menonjol pada subjek yang berada pada kategori sedang. Hasil wawancara yang peneliti lakukan menggambarkan para subjek merasa bosan dengan pertemanan yang mereka miliki saat ini. Setelah peneliti melakukan wawancara lebih lanjut, mereka pun mengaku merasa jenuh karena harus tinggal di panti asuhan dengan ruang lingkup pertemanan mereka hanyalah dengan anak-anak panti asuhan saja. Kontak dengan teman di luar panti 
sangat minim mereka lakukan karena adanya peraturan yang diterapkan di panti asuhan. Selain itu, para subjek mengaku dalam suatu diskusi sekalipun, pendapat, ide, dan saran mereka seringkali diabaikan begitu saja oleh teman-temannya.

Sebanyak 47 subjek atau 38.21 persen subjek memiliki kesepian yang berada pada kategori tinggi dan dapat dilihat dari aspek kesepian emosional. Hasil wawancara yang peneliti dapatkan, para subjek sering merasa tidak berarti bagi siapapun. Perasaan ini muncul ketika mereka merasa tidak ada yang peduli dan memperhatikan mereka, terutama di saat mereka sedang sakit. Selain pada aspek kesepian emosional, aspek kesepian sosial juga dominan pada para subjek yang memiliki kesepian yang berada pada kategori tinggi. Diketahui dari wawancara yang telah peneliti lakukan, para subjek mengaku masih merasa asing di panti asuhan. Perasaan asing ini muncul karena mereka merasa tidak ada seorang pun yang menanyakan kondisi mereka ketika mereka tidak nampak dan muncul dalam kelompok. Pertemanan yang mereka miliki hanya berdasarkan tatap muka yang mereka lakukan sehari-hari dan di lingkungan sekolah dan panti saja.

Tidak terdapat subjek yang memiliki kesepian pada kategori rendah. Wawancara lanjutan yang telah peneliti lakukan pada para subjek menggambarkan bahwa banyak di antara mereka merindukan teman-teman mereka dulu. Terlebih ketika sedang memiliki masalah. Para subjek mengaku merasa keberadaan mereka sering kali diabaikan oleh teman-teman yang lain. Hal ini membuat para subjek lebih sering memendam segala permasalahannya seorang diri dan membuat mereka tidak mudah percaya akan pertemanan yang sedang mereka jalani.

Berdasarkan wawancara yang telah dilakukan, dapat diketahui bahwa perasaan kesepian yang dimiliki oleh para subjek juga dipengaruhi oleh minimnya kedekatan sosial yang terjalin. Para subjek mengaku ingin menjalin pertemanan dan dekat dengan anak-anak lainnya, namun niat pertemanan tersebut tidak terlaksana karena alasan yang mereka sendiri tidak ketahui. Sehingga para subjek merasa asing dengan panti dan bosan dengan pertemanan yang ada di sana.

Bordens dan Horowitz (2008) berpendapat bahwa perasaan kesepian selalu disertai dengan perasaan negatif seperti depresi, kecemasan, ketidakbahagiaan, dan ketidakpuasan yang diasosiasikan dengan pesimisme, self-blame, dan rasa malu. Hal ini sesuai dengan apa yang terjadi pada beberapa remaja yang tinggal di Panti Asuhan Al Jam'iyatul Washliyah Pulo Brayan. Dimana remaja yang merasakan kesepian cenderung merasakan perasaan-perasaan negatif seperti sedih, kecewa, marah, dan merasa diasingkan oleh teman sebayanya.

Keterbatasan penelitian ini terdapat pada jumlah subjek yang hanya berjumlah 123 remaja yang berusia 13-16 tahun, berstatuskan yatim/piatu/yatim-piatu, dan tinggal menetap di Panti Asuhan Al Jam'iyatul Washliyah Pulo Brayan Medan. Keterbatasan ini terjadi karena terbatasnya jumlah subjek yang memenuhi kriteria subjek penelitian. Hal lain yang menjadi kelemahan penelitian ini adalah peneliti hanya menggunakan salah satu trait kepribadian yakni kepribadian ekstraversi saja. Sehingga, tidak dapat diketahui 
hubungan trait-trait kepribadian lainnya seperti agreeableness, conscientiousness, openness to experience, dan neuroticism dengan kesepian.

\section{SIMPULAN DAN IMPLIKASI}

Berdasarkan hasil penelitian yang telah diperoleh, dapat dipahami bahwa hipotesis yang diajukan dalam penelitian ini dapat diterima, dimana terdapat hubungan negatif yang signifikan antara kepribadian ekstraversi dengan kesepian pada remaja yang tinggal di Panti Asuhan Al Jam'iyatul Washliyah Pulo Brayan Medan. Hal tersebut direfleksikan dari hasil koefisien korelasi Pearson Product Moment dengan r=-0.731, p<0.001. Kepribadian ekstraversi memberikan kontribusi sebesar 53.4\% terhadap kesepian pada subjek penelitian dan $46.6 \%$ sisanya dipengaruhi oleh faktor lain yang tidak diteliti.

Implikasi penelitian ini bagi para peneliti selanjutnya, kiranya dapat menemukan variabel moderator yang menghubungkan kepribadian ekstraversi dengan kesepian ataupun dapat menguji traits kepribadian lainnya dengan kesepian. Penelitian ini juga diharapkan dapat menjadi masukan bagi panti asuhan agar dapat membantu mengurangi perasaan kesepian yang dimiliki remaja yang tinggal di panti asuhan dengan cara mendorong remaja untuk lebih terbuka dengan lingkungan sosialnya dan bersedia menjadi pendengar aktif dalam mendengar keluh-kesah dan permasalahan yang dialami remaja yang tinggal di panti asuhan karena kebutuhan anak panti asuhan tidak hanya sebatas kebutuhan sandang dan pangan semata. Anak-anak yang tinggal di panti asuhan juga membutuhkan pemenuhan kebutuhan psikologis seperti perhatian orang tua yang dapat diberikan oleh pengurus, pengawas, maupun pimpinan panti asuhan.

\section{REFERENSI}

Baron, R. A., \& Branscombe, N. R. (2012). Social Psychology $13^{\text {th }}$ Edition. United States of America : Pearson Education.

Bevinn, S. J. (2011). Psychology of Loneliness. New York : Nova Science Publishers, Inc.

Bordens, K. S., \& Horowitz, I. A. (2008). Social Psychology: Third Edition. United States of America : Freeload Press.

Cecen, A. R. (2007). The Turkish Short Version of The Social and Emotional Loneliness Scale for Adults (SELSA-S): Initial Development and Validation. Social Behavior and Personality, 35(6), 717-734.

Johnson, G. Y. (2014). I Am Here: Opening The Windows To Life And Beauty. United Kingdom : O-Books.

Margalit, M. (2010). Lonely Children and Adolescents. London : Springer Science + Business Media LLC. 
Myers, D. G. (2012). Social Psychology. United States of America : Mc Graw Hill.

Nayyar, S., \& Singh, B. (2011). Personality Correlates of Loneliness. Journal of the Indian Academy of Applied Psychology January 2011, 37(1)), 163-168.

Priyatno, D. (2011). Teknik Mudah dan Cepat Melakukan Analisis Data Penelitian dengan SPSS. Yogyakarta : Gaya Media.

Riva, P., \& Eck, J. (2016). Social Exclusion: Psychological Approaches to Understanding and Reducing its Impact. Switzerland : Springer Nature.

Sarinah. (2017). Minat Berwirausaha Ditinjau dari Kepribadian Extraversion pada Mahasiswa Fakultas Ekonomi Universitas Dharmawangsa Medan. Jurnal Diversita, 3(1), 32-39.

Siswanto, Susila, \& Suyanto. (2017). Metodologi Penelitian Kombinasi Kualitatif Kuantitatif Kedokteran dan Kesehatan. Klaten : Bossscript.

Utami, D. R., Ahmad, R., \& Ifdil. (2017). Tingkat Kesepian Remaja di Panti Asuhan X Kota Padang. Jurnal Konseling GUSJIGANG, 3(1), 1-6.

Vanhalst, J., Goosens, L., Luyckx, K., Scholte, R. H. J., \& Engels, R. C. M. E. (2013). The Development of Loneliness from Mid- to Late Adolescence: Trajectory Classes, Personality Traits, and Psychosocial Functioning. Journal of Adolescence 36(6), 1305-1312.

Victor, C., Sasha, S., \& John, B. (2009). The Social World of Older People. New York : Two Penn Plaza.

Weiner, I. B. (2003). Handbook of Psychology, Volume 5: Personality and Social Psychology. New Jersey : John Wiley \& Sons, Inc. 